\title{
GENDER DALAM PERSPEKTIF ISLAM: STUDI KEPEMIMPINAN PADA LEMBAGA EKSEKUTIF DAN LEGISLATIF DI SULAWESI TENGAH
}

\author{
Gusnarib Wahab \\ STAIN Datokarama Palu, Jl. Diponegoro 23 Palu \\ e-mail: gusnarib@gmail.com
}

\begin{abstract}
This paper deals with gender women's leadership in the executive and legislative boards in Central Sulawesi from the perspective of Islam. The method of data collection includes documentation, observation and depth interview. The Data collected were analyzed by employing a qualitative method. The results of the research shows that (1) Islam gives the same role to women to get involved in public life as men; (2) Women's representativeness in the executive and legislative boards (governor office) in Central Sulawesi can be said to be relatively low.

$$
\begin{aligned}
& \text { هذا البحث هو محاولة لتبيان قضية ما يعرف حاليا بـ جندر = gender وهو } \\
& \text { نوع بشرى من حيث الذكورة و الأنوثة , و ذللك فى ضوء الدر اسة الإسلامية }
\end{aligned}
$$

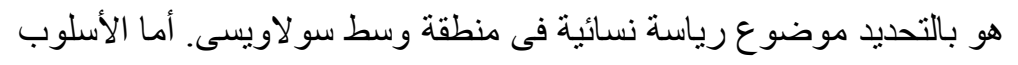

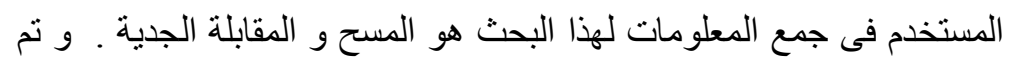

$$
\begin{aligned}
& \text { تحليل المحتوى لهذا البحث فى صورة وصفية نوعية. و ينتهى البحث إلى إلى }
\end{aligned}
$$

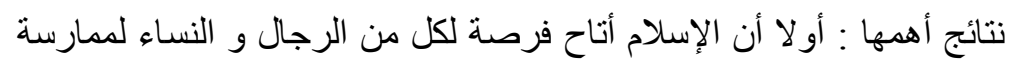

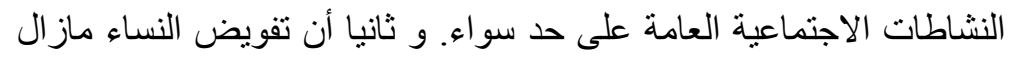

$$
\begin{aligned}
& \text { متدنئا لدى الهيئات التشريعية و التنفيذية فى كل من مدينة بالو و مركز } \\
& \text { دونجلا. }
\end{aligned}
$$

Kata Kunci: gender perspektif Islam, kepemimpinan perempuan, Lembaga Eksekutif, Lembaga Legislatif 


\section{PENDAHULUAN}

Di Indonesia-dalam statistika kependudukan-kaum perempuan memliki jumlah yang lebih besar dari pada kaum pria. Kenyataan ini telah menjadikan perempuan berada di tengah-tengah kehidupan kaum pria. Kondisi perempuan tersebut mengantar kaum perempuan bergeser posisi dari orang yang dipimpin menjadi orang yang memimpin. Fenomena ini dapat diartikan bahwa gerakan dan potensi kepemimpinan kaum mulai tumbuh dan berkembang, yaitu tidak saja untuk dipimpin tetapi juga memimpin. Permasalahan yang timbul kemudian adalah bagaimana kaum perempuan diberikan kesempatan untuk mendapatkan penghormatan layaknya pemimpin pria. Hal ini tentu saja untuk menjaga kemungkinan akan munculnya berbagai upaya untuk menghalangi kaum perempuan dalam wujud boikot, baik dari segi konsep maupun doktrin bahwa perempuan tidak diperkenankan untuk menjadi pemimpin apa pun juga.

Problem gender merupakan isu dan tema sentral yang secara populer diperbincangkan dalam masyarakat dewasa ini. Definisi gender (gender terms) dapat dikategorikan ke dalam tiga bentuk, yaitu beban kerja, peran gender dan relasi gender. Namun, perlu disadari secara bijak bahwa isu perempuan dekade terakhir ini sangat sulit untuk dipertentangkan dan dipersoalkan kecuali melalui penelitian dengan menggunakan metode yang kontemporer (Abdullah, 1996: 10). Pada tulisan ini dikemukakan beberapa istilah pendekatan yang digunakan dalam studi gender, yaitu (1) Beban Kerja. Kaum perempuan yang sangat populer peran "domestiknya" menjadikan banyak orang beranggapan bahwa tugas-tugas utama perempuan adalah "Ibu Rumah Tangga". Istilah ini memunculkan mainstream bahwa peran kaum perempuan sehari-harinya terbatas pada lingkup keluarga; (2) Peran Gender. Dari segi peran gender, gender mengkaji bahwa terjadinya suatu bias gender terhadap peran gender itu dapat terjadi karena perilaku individu, di mana perilaku setiap individu merupakan produk sosial; dan (3) Relasi Gender. Dari segi ini, konsep dan relasi sosial yang melihat pembagian kerja dari jenis gendernya, tidak didasarkan pada pemahaman yang bersifat normatif secara biologis. Demikian paradigma yang berkembang yang melanda kaum perempuan selama ini.

Gender, secara etimologis, artinya jenis kelamin (Partanto \& Dahlan, 1994:197). Gender sebagai alat analisis umumnya digunakan oleh penganut aliran ilmu sosial konflik yang memusatkan perhatian pada ketidakadilan struktural dan sistem. Gender adalah perbedaan yang bukan biologis dan bukan kodrat Tuhan. Perbedaan biologis dan perbedaan jenis kelamin adalah kodrat Tuhan sehingga secara permanen berbeda. Sementara gender adalah behavioral differences 
antara laki-laki dan perempuan yang socially-constructed, yaitu perbedaan yang bukan kodrat atau bukan ciptaan Tuhan, melainkan diciptakan oleh kaum laki-laki dan perempuan melalui proses panjang dalam kehidupan sosial dan budaya (Fakih, 1996:45). Perbedaan perilaku laki-laki dan perempuan tidak sekedar perbedaan biologis, namun melalui proses sosial dan kultural. Oleh karena itu, gender berubah dari waktu ke waktu, dari tempat ke tempat, dan bahkan dari kelas ke kelas, sedangkan jenis kelamin akan tetap tidak berubah. Dengan demikian, gender tidak hanya sekedar pembicaraan tentang jenis kelamin. Namun demikian, dalam prakteknya, khususnya pada kehidupan sosial, istilah ini lebih diarahkan kepada jenis kelamin perempuan.

Gerakan-gerakan sosial khususnya yang didukung oleh idiologi natural dan kultural menyadarkan perempuan untuk terlibat aktif dalam ruang publik. Gerakan ini telah memberikan pengaruh yang besar terhadap partisipasi kaum perempuan sehingga partsipasi mereka meningkat dengan pesat. Hal ini dapat dilihat dari dua hal: Pertama, dari sudut jumlah perempuan yang terlibat dalam berbagai sektor kehidupan telah menunjukkan perkembangan yang signifikan; dan kedua, jumlah bidang atau jenis pekerjaan yang dapat dimasuki oleh perempuan bertambah banyak (Abdullah, 1996:11). Gender adalah pembagian peran manusia pada maskulin dan femenim yang di dalamnya terkandung peran dan sifat yang dilekatkan oleh masyarakat kepada kaum laki-laki dan perempuan dan dikonstruksikan secara sosial atau kultural. Peran dan sifat gender ini dapat dipertukarkan, tidak bersifat permanen, dan berbeda pada daerah, kultur dan periode tertentu. Peran laki-laki dan perempuan yang dikonstruksi oleh kondisi sosial dan kultural inilah yang bisa menimbulkan ketidakadilan gender dalam bentuk marginalasi, subordinasi, streotip, diskriminasi, kekerasan, beban kerja ganda dan ketidakproporsionalan (Roqib, 2003:111).

Rasulullah saw. telah memulai suatu tradisi baru dalam memandang kaum perempuan. Ia melakukan dekonstruksi terhadap cara pandang masyarakat Arab yang masih didominasi cara pandang Fir'aun. Setiap kelahiran bayi perempuan disambut dengan muka masam. Karena itu, secara demonstratif Rasulullah sering membanggakan anak-anak perempuannya di hadapan para sahabat. Tanpa malu-malu, Rasulullah juga menggandeng anak perempuannya di muka umum (Hasyim, 1999:6). Sebagai manusia pilihan Tuhan, Muhammad Rasulullah memberikan teladan bagi perlakukan baik terhadap kaum perempuan. Sikap teladan Rasulullah yang menonjol adalah keadilannya dalam memperlakukan istri-istrinya. Tidak pernah didengar sebuah riwayat pun yang menyatakan Rasulullah berbuat 
tidak adil terhadap istri-istrinya. Memang antara satu istri dengan istriistrinya yang lain terkadang saling cemburu dan iri hati, namun Rasulullah berusaha membagikan apa-apa yang dimilikinya kepada mereka secara merata tanpa ada pengecualian (Hasyim, 1999:7).

Berdasarkan pemikiran di atas, fokus masalah penelitian ini adalah bagaimana pandangan Islam tentang gender jika dikaitkan dengan kepemimpinan perempuan di lembaga eksekutif dan legislatif di Sulawesi Tengah. Masalah ini dijabarkan kedalam dua submasalah, yakni (1) Bagaimana pandangan Islam tentang gender, (2) bagaimana peran kepemimpinan perempuan pada lembaga eksekutif dan legislatif di Sulawesi Tengah. Tujuannnya adalah untuk mengetahui; (1) objektivitas ajaran Islam dalam memposisikan kepemimpinan perempuan dalam kehidupan publik (2) pandangan masyarakat Sulawesi Tengah tentang peran perempuan di lembaga eksekutif dan legislatif, dan (3) apakah penolakan terhadap perempuan sebagai pemimpin karena perintah agama, ataukah hanya persepsi masyarakat.

\section{METODE PENELITIAN}

Penelitian ini dilakukan di Sulawesi Tengah. Teknik pengambilan sample yang digunakan ialah purposive sampling sehingga yang menjadi lokasi utama penelitian adalah kantor gubernur (lembaga eksekutif) dan kantor DPR (lembaga legislatif) Provinsi Sulawesi Tengah. Pertimbangan peneliti adalah kedua lembaga tersebut merupakan representasi masyarakat Sulawesi Tengah. Penelitian ini ialah penelitian kualitatif sehingga menghasilkan data deskriptif, berupa kata-kata tertulis, atau lisan dari orang-orang atau perilaku yang diamati.

Penelitian ini lebih diarahkan kepada pendekatan latar atau individu secara utuh holistik. Jadi, peneliti tidak mengisolasi individu atau organisasi ke dalam variabel atau hipotesis. Adapun informan dalam penelitian ini, dibagi ke dalam tiga macam, yaitu informan pangkal, informan biasa dan informan ahli. Informan tersebut dipilih secara purposive.

Teknik pengumpulan data yang digunakan adalah observasi dan wawancara mendalam (depth interview). Data yang telah dikumpulkan, berupa catatan lapangan, catatan wawancara, rekaman kaset, dokumen, diatur, diurut, dikelompokkan, diberi kode, dan dikategorisasikan selanjutnya dianalisis secara deskriptif interpretatif 


\section{PEMBAHASAN DAN ANALISIS}

\section{Gender dalam Islam}

Fenomena tampilnya perempuan dalam berbagai sektor menunjukkan bahwa saat ini, baik di Barat maupun di dunia Islam terutama di Indonesia, telah terjadi pergeseran paradigma pemikiran, perubahan persepsi masyarakat dalam menakar harga perempuan di pentas sosial politik. Perubahan itu, merupakan sebuah proses panjang dari orientasi sosial dan kultural yang selama ini didominasi oleh arogansi peradaban patriarkhi yang menempatkan perempuan sebagai kelompok marginal dalam tatanan kehidupan sosial. Kesadaran itu tidak saja menawarkan struktur sosial yang equilibrium antara struktur patriarki dan matriarki, tetapi juga menantang sejauh mana objektivitas dan supremasi ajaran Islam dalam menempatkan posisi perempuan secara layak dan proportional berdasarkan Alquran.

Fenomena tampilnya beberapa pemimpin perempuan, baik sebagai perdana menteri maupun presiden pada beberapa Negara, termasuk Indonesia, telah memicu kontroversi dan polemik pemikiran antara beberapa ulama dan cendekiawan di tanah air sehingga melahirkan "Kongres Umat Islam Indonesia" tahun 1999 yang kemudian merekomendasikan bahwa Islam melarang seorang perempuan menjadi kepala negara atau presiden. Rekomendasi kontroversial ini, tidak sertamerta meredam perbedaan pendapat di kalangan ulama dan umat Islam, bahkan semakin memicu polemik seputar penafsiran terhadap beberapa ayat Alquran yang berkaitan dengan status kepemimpinan perempuan sebagai presiden.

Penolakan kepemimpinan perempuan, baik dalam pengertian imâm, sult $\square$ ânah, khaliffah, maupun dalam pengertian sekarang sebagai presiden, memamg sejak dahulu telah menyebabkan deferensiasi pendapat di kalanngan ulama. Perbedaan ini dipicu oleh banyak faktor antara lain adanya perbedaan interpretasi terhadap pertama surah Al-Nisâ' (4): 34 dan kedua terhadap hadis dari Abî Bakrah, yang masing-masing diuraikan sebagai berikut:.

Pertama, surah al-Nisâ' (4):34 :

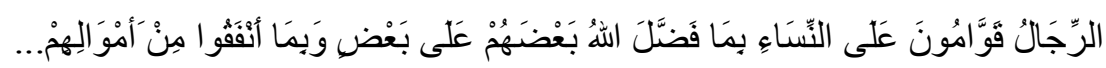


Terjemahnya :

Kaum laki-laki itu adalah pemimpin bagi kaum perempuan oleh karena Allah telah melebihkan sebahagian mereka (laki-laki) atas sebahagian yang lain (perempuan) dan karena mereka (laki-laki) telah menafkahkan sebahagian dari harta mereka. (Departemen Agama RI, 1989:123).

Berdasarkan realitas sejarah awal Islam, nabi tidak pernah melarang perempuan melakukan kreativitas. Bahkan dalam Alquran tidak satu pun ayat yang melarang perempuan menjadi pemimpin, justeru sebaliknya Alquran secara spesifik menuturkan kisah legendaris Ratu Balqis dalam memimpin negeri Saba. Boleh jadi maksud Tuhan mengisahkan ini tidak lain adalah untuk memberitahukan kepada kita bahwa ternyata perempuan juga mampu memimpin negara meskipun Ratu Balgis adalah penyembah api.

Kedua, hadis tentang kepemimpinan puteri Kisra' Anusyirwan.

حدثنا عثمان بن الهيتم حدثنا عوف عن الحسن ابن بكرة قال لقد نفعنى الله بكلملة ايام الجمل

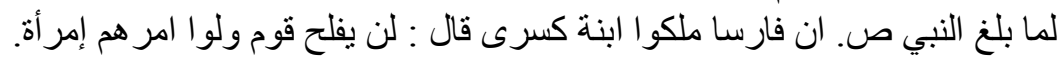
Terjemahnya:

Telah menyampaikan kepada kami 'Uthmân bin al-Haitam, ('Uthmân bin al-Haitam) berkata, telah menyampaikan kepada kami 'Auf dari Hasan bin Abîi Bakrah, dia berkata : Sungguh Allah telah memberi petunjuk kepadaku, suatu perkataan yang aku dengar dari Rasulullah saw., (berita tentang penduduk Persia) yang menyerahkan kekuasaan kepada puteri kaisarnya (mengangkat-nya sebagai Raja pengganti Bapaknya). Rasulullah saw., bersabda: Tidak akan sukses suatu bangsa yang menyerahkan urusan kenegaraannya kepada perempuan (HR. Bukhari, Juz 2, t.th.: 192).

Kontroversi pemikiran tentang gender seperti pandangan, telah melahirkan perdebatan panjang sekalipun dalam konteks realitas politik, telah berhasil menampilkan perempuan menjadi Presiden. Akan tetapi dalam realitas sosial, para cendekiawan, ulama maupun lapisan sosial paling bawah masih menyisakan pro-kontra. Hal itu berimplikasi serius pada terciptanya dikotomisasi pemikiran masyarakat dalam merespon boleh tidaknya perempuan diangkat menjadi kepala negara atau presiden. Masyarakat terpola ke dalam 
dua kelompok, menerima atau menolak. Akan tetapi, dasar penolakan dan penerimaan itu masing-masing memiliki kekuatan argumentasi yang seimbang.

Jamâl al-Dîn Muhammad Mahmûd, sebagaimana dikutip M. Quraish Shihab (1993:14), mengatakan bahwa tidak ditemukan satu ketentuan agama pun yang dapat dipahami sebagai larangan keterlibatan perempuan dalam bidang politik (seperti menjadi pemimpin/kepala negara), atau ketentuan agama yang membatasi bidang tersebut hanya pada kaum laki-laki..

Sejarah Islam juga menunjukkan betapa kaum perempuan terlibat dalam berbagai bidang kemasyarakatan, tanpa kecuali. Alquran menguraikan permintaan para perempuan di zaman nabi untuk melakukan bay'ah (janji setia kepada nabi dan ajarannya), sebagaimana disebutkan dalam Alquran surah al-Mumtahanah (60): 12:

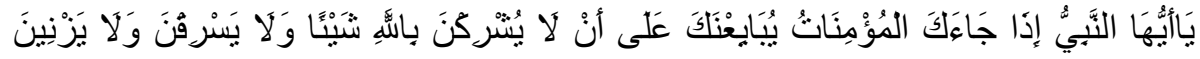

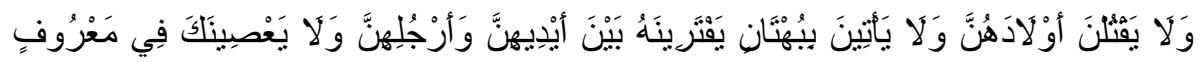

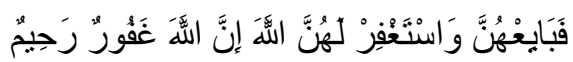

Terjemahnya :

Hai nabi, apabila datang kepadamu perempuan-perempuan yang beriman untuk mengadakan janji setia, bahwa mereka tidak akan mempersekutukan sesuatu pun dengan Allah; tidak akan mencuri, tidak akan berzina, tidak akan membunuh anakanaknya, tidak akan berbuat dusta yang mereka ada-adakan antara tangan dan kaki mereka, dan tidak akan mendurhakaimu dalam urusan yang baik, maka terimalah janji setia mereka dan mohonlah ampunan kepada Allah untuk mereka. Sesungguhnya Allah Maha Pengampun lagi Maha Penyayang (Departemen Agama RI, 1989:925).

Kenyataan sejarah menunjukkan sekian banyak kaum perempuan yang terlibat dalam soal-soal politik praktis. Umm Hâni misalnya dibenarkan sikapnya oleh Nabi Muhammad saw. ketika memberi jaminan keamanan sementara kepada orang musyrik, (jaminan keamanan merupakan salah satu aspek bidang politik) (Shihab, 1993:15). 
Perbedaan cara pandang para pakar terhadap peran gender khususnya perempuan bermula ketika mereka memahami ayat Alquran, misalnya perbedaan pemahaman mereka terhadap teks Alquran surah Al-Nisâ' (4): 1:

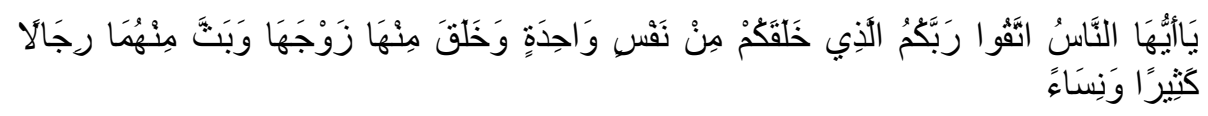

Terjemahnya:

Hai sekalian manusia, bertaqwalah kepada Tuhanmu yang telah menciptakan kamu dari seorang diri, dan dari padanya Allah menciptakan istrinya, dan dari pada keduanya Allah memperkembang biakkan laki-laki dan perempuan yang banyak (Departmen Agama RI, 1989:114)

Perbedaan pendapat para mufasir tersebut tentang penciptaan perempuan, terletak pada perbedaan dalam memahami kata nafs. Mufasir klasik memahami kata nafs sebagai Adam. Mereka memahami kata zaujaha (harfiyahnya adalah "pasangan"), mengacu kepada istri Adam yaitu Hawa. Mengingat ayat tersebut menerangkan bahwa pasangan tersebut diciptakan dari nafs yang berarti Adam, maka para mufasir klasik menafsirkan istri Adam (perempuan) diciptakan dari Adam sendiri (Al-Munawwar dalam Hasyim, 1999: 15). Cara pandang ini kemudian menimbulkan kesan negatif terhadap perempuan, karena perempuan berasal dari laki-laki, sehingga ia tidak bisa sejajar dengan laki-laki. Hal ini tentunya merupakan penafsiran yang merugikan gerakan gender yang menuntut adanya kesetaraan antara laki-laki dan perempuan.

Beberapa pakar tafsir kontemporer seperti Muhammad Abduh dalam kitab al-Manâr-nya, tidak sependapat dengan kalangan mufasirîn terdahulu. Abduh memahmi nafs itu dengan jenis. Sedangkan menurut al-Thabaththabai, surah Al-Nisâ' (4) ayat 1 menegaskan bahwa perempuan Adam diciptakan dari jenis yang sama dengn Adam, dan pendapatnya itu tidak mendukung sama sekali pendapat-pendapat mufasirîn masa lalu yang beranggapan bahwa Hawa diciptakan dari tulang rusuk Adam. Sejalan dengan itu, Rashid Rid $\square$ a menyatakan ide semacam ini sama dengan apa yang terdapat dalam Kitab Perjanjian Lama yang menyatakan Tuhan mencabut 
tulang rusuk Adam dan membalutnya dengan daging yang kemudian dibuat seorang perempuan.

Ide penciptaan Hawa dari tulang rusuk Adam tidak berbeda dengan cerita-cerita israiliyyat yang bersumber dari agama samawi sebelumnya, Yahudi dan Kristen. Ada asumsi teologis yang menyebabkan munculnya ketidaksetaraan laki-laki dan perempuan dalam agama samawi tersebut: (1) bahwa ciptaan yang utama adalah laki-laki dan bukan perempuan, karena perempuan diyakini telah diciptakan dari tulang rusuk Adam sehingga secara ontologis bersifat derivatif dan sekunder; (2) perempuan adalah penyebab utama kajatuhan dan pengusiran manusia dari surga Aden. Karena itu, anak perempuan (Hawa) harus dipandang dengan rasa benci, curiga dan jijik; dan (3) perempuan tidak hanya dari laki-laki tetapi juga untuk laki-laki sehingga keberadaannya bersifat istrumental dan tidak memiliki makna yang mendasar (Al-Munawar dalam Hasyim, 1999:17).

Dalam Alquran, tidak ada satu ayat pun yang mendukung pendapat yang menyatakan bahwa asal kejadian perempuan dari tulang rusuk laki-laki, bahkan Alquran mendukung prinsip kesamaan dan kesetaraan di hadapan Tuhan dengan menekankan unsur-unsur persamaan dalam kejadian Adam dan Hawa (perempuan) seperti dalam Alquran surah Al-Isrâ' (17):70:

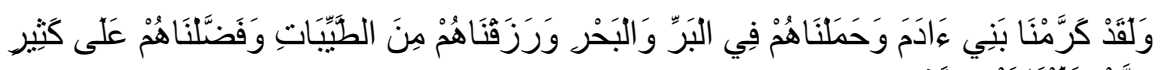

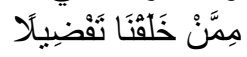

Terjemahnya:

Sesungguhnya Kami memuliakan anak-anak Adam, Kami angkut mereka di daratan dan di lautan (untuk memudahkan mereka mencari kehidupan). Kami beri mereka rezeki yang baik-baik dan kami lebihkan mereka dengan kelebihan yang sempurna atas kebanyakan makhluk-makhluk yang diciptakan (Departemen Agma RI : 1989: 435)

Dalam surah Âli Imrân (3): 195 disebutkan:

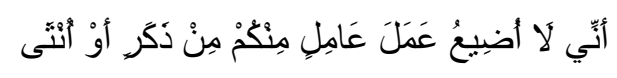


Terjemahnya:

Sesungguhnya Aku tidak mensia-siakan amal orang-orang yang beramal, baik laki-laki maupun perempuan (Departemen Agama RI, 1989:110).

Perbedaan penafsiran tersebut, kadang disebabkan tingkat pemahaman mufasir yang berbeda. Selain dipengaruhi pula oleh latar belakang geografis dan budaya, termasuk perbedaan ulama yang hidup di kalangan atau lingkungan istana dan yang tidak. Demikian jelaslah bahwa Islam sebagai salah satu agama samawi, yang menjadikan Alquran dan hadis sebagai sumber rujukannya, selalu memandang kaum perempuan sebagai makhluk manusia yang bermartabat dan mempunyai hak dan kewajiban yang sama dengan kaum pria. Islam juga mengakui bahwa antara pria dan perempuan memiliki perbedaan spesifik yang bersifat alami. Untuk itu, perlu saling menghargai dan menghormati antara kedua jenis manusia ini.

\section{Analisis Prospektif Kepemimpinan Perempuan di Sulawesi Tengah}

Realitas dan prospektif perempuan di Sulawesi Tengah hampir tidak jauh berbeda dengan nasib dan peran perempuan di daerahdaerah lainnya di Indonesia. Perempuan sebagai kelompok masyarakat selalu ditempatkan pada posisi marginal dibandingkan dengan laki-laki, baik pada posisi eksekutif maupun legislatif. Hal inilah yang membuat perempuan di daerah ini selalu berjuang untuk mendapatkan hak-haknya sebagai warga masyarakat dan warga bangsa.

Hasil pengamatan penulis pada dua instansi pemerintah yaitu Kantor Gubernur Sulawesi Tengah (representasi lembaga eksekutif) dan Kantor Sekretariat DPR Provinsi Sulawesi Tengah (representasi dari lembaga legislatif), menunjukkan bahwa peran dan posisi perempuan pada kedua lembaga tersebut masih belum menjamin hakhak perempuan sebagai warga bangsa yang memiliki peran strategis di bidang politik dan kemasyarakatan.

Tabel 1. Perempuan yang Memiliki Jabatan pada Kantor Gubernur Provinsi Sulawesi Tengah

\begin{tabular}{|c|c|c|c|c|}
\hline No. & URAIAN & & JUMLAH & KET \\
\hline 1. & Pegawai perempuan & & 12 orang & Kondisi pegawai \\
\hline 2. & $\begin{array}{l}\text { Perempuan yang } \\
\text { jabatan }\end{array}$ & memiliki & 7 orang & $\begin{array}{l}\text { perempuan di } \\
\text { kantor gubernur } \\
\text { Sulawesi Tengah }\end{array}$ \\
\hline
\end{tabular}


Tabel 2. Perempuan yang Memiliki Jabatan pada Kantor DPR TK I Provinsi Sulawesi Tengah

\begin{tabular}{lllll}
\hline No. & \multicolumn{2}{c}{ URAIAN } & \multicolumn{1}{c}{ JUMLAH } & \multicolumn{2}{c}{ KET } \\
\hline 1. & Pegawai perempuan & & 11 orang & Kondisi pegawai \\
2. & $\begin{array}{l}\text { Perempuan yang } \\
\text { jabatan }\end{array}$ & memiliki & 1 orang & $\begin{array}{l}\text { perempuan } \\
\text { kantor di } \\
\end{array}$ \\
& & & Provinsi & DPR \\
& & Sulawesi Tengah \\
\hline
\end{tabular}

Dari data di atas dapat dipahami bahwa perempuan pada kedua lembaga tersebut belum mencerminkan kesetaraan gender. Hal ini menuai protes dari beberapa perempuan yang sempat diwawancarai, di mana mereka mengharapkan agar perempuan diberi hak yang sama dan tidak perlu dibatasi.

Yustina Pabarungan, pegawai Kantor Gubernur Sulawesi Tengah, mengatakan :

Perempuan tidak perlu diberi batasan dalam bekerja, karena mereka juga mampu bekerja dan bahkan lebih tekun dalam pekerjaannya serta aktif menjalankan tugas-tugas yang diberikan atasannya kepadanya" (Wawancara dengan Yustina Pabarungan, tanggal 4 Oktober 2004 di Kantor Gubernur Provinsi Sulawesi Tengah).

Lain halnya dengan $\mathrm{Hj}$. Zulfikar B. Lamakarate, pegawai pada Kantor DPR Proivinsi Sulawesi Tengah, mengatakan :

Perempuan boleh bekerja tetapi tidak boleh melupakan kondratnya sebagai perempuan. Mereka dapat bekerja selama pekerjaan tersebut dapat dibenarkan oleh agama". (Wawancara dengan Zulfikar B. Lamakarate, di Kantor DPR Provinsi Sulawesi Tengah tanggal 6 Oktober 2004).

Dengan demikian pemenuhan hak-hak atas perempuan dapat dilakukan dengan tetap memperhatikan batasan-batasan kondratnya sebagai perempuan. Pemberian hak ini mesti dilakukan karena ia merupakan tuntutan kemanusiaan yang tidak boleh diabaikan.Hak asas perempuan yang dimaksud adalah hak asasi manusia, di mana ia merupakan satu ungkapan untuk menjelaskan bahwa tindakan pelanggaran terhadap hak perempuan sama dengan tindakan pelanggaran terhadap hak asasi manusia (Suhardiany, 2002:24). Jadi, 
penempatan yang marginal terhadap perempuan di daerah ini dapat dinilai sebagai suatu pelanggaran hak asasi manusia secara keseluruhan.

Dalam konteks ini perjuangan penegakan hak perempuan tidak hanya dilihat dalam konteks kepentingan perempuan semata, melainkan juga pada kepentingan menegakkan nilai-nilai kemanusiaan dan keadilan. Hakikat gerakan perempuan merupakan suatu bentuk perlawanan untuk mewujudkan hak asasi perempuan, kebebasan, keadilan, persamaan dan keterbukaan serta partisipasi perempuan dalam kehidupan berbangsa dan bernegara.

Eksistensi perempuan sebagai warga Negara, khususnya di Sulawesi Tengah dapat dilihat dari tingkat partisipasi aktif perempuan dalam berbagai upaya pembangunan dan pengelolaan Negara, baik di ruang politik, ekonomi, sosial maupun budaya, serta HANKAM. Realitas peran dan posisi perempuan hingga abad ke-21 ini perlu ditinjau sebagai satu permasalahan terhadap wacana demokrasi yang digulirkan sebagai isu global, dengan melihat pelaksanaan asas-asas demokrasi pada penyelenggaraan negara, yaitu adanya partisipasi dari seluruh warga negara. Tingkat keterlibatan perempuan tidak sebangun dengan jumlah perempuan sebagai mayoritas di banyak negara karena menjadi minoritas dalam pembangunan dan praktik-praktik pemerintahan.

Pembangunan berwawasan gender dalam berbagai aspek, pendidikan, kesehatan, penerangan, pembangunan sarana fisik, dan lain-lain, menjadi tugas dan kewajiban pemerintah untuk memberi kemudahan bagi setiap peran social dan perbedaan-perbedaan dalam peran social tersebut. Proyek pembangunan dengan sasaran perempuan sering kali masih pada pemahaman stereotype perempuan, yaitu pada peran-peran tradisional para ruang domestik, seperti menambah keterampilan perempuan dalam menjahit, memasak, dan lain-lain. Hal ini tidak memberi pemahaman dan pengetahuan baru serta nilai lebih pada perempuan. Perdebatan antara pendekatan WID (Women in Development) dan GAD (Gender and Development) memunculkan pendekatan gender mainstream untuk melihat peran dan posisi perempuan dalam pembangunan.

Pemunculan gender mainstreaming dalam melihat partisipasi perempuan pada pembangunan adalah dengan adanya pegawai pemerintah dan jajaran birokrat yang memiliki sensitive gender. 
Political will sulit diciptakan tanpa disertai keterlibatan perempuan secara penuh dalam proses pembentukan kebijakan. Kebijakan berwawasan gender perlu dievaluasi untuk melihat apakah kebijakan dan program pembangunan tersebut telah memberi keuntungan bagi kaum perempuan juga (Suhardiany, 2002: 34).

Di beberapa daerah sudah dilakukan pengawalan oleh gerakan perempuan yang berhubungan dengan gelar gender budget, sejauh mana pembangunan sudah memasukkan kebutuhan perempuan perlu memenuhi beberapa prasyarat jika terlibat dalam aksi-aksi pemberdayaan perempuan dunia ketiga, agar dapat menangani masalah-masalah yang ada yaitu: (1) memiliki pengetahuan yang lebih mengenai keadaan social ekonomi dan politik budaya di negara masing-masing dengan mengetahui kebutuhan-kebutuhan perempuan untuk bisa bertahan hidup. Kerja dilakukan berintegrasi dengan para pakar/ahli untuk mengerti kebutuhan-kebutuhan dasar perempuan sehingga bias melakukan pola bottom up; (2) memakai perspektif feminis, yaitu perempuan dan laki-laki memperoleh kesempatan dan akses yang sama dalam berbagai hal; (3) Pada akhirnya pengelolaan negara harus memakai pola bottom-up sehingga proyek-proyek pembangunan mencapai sasaran yang tepat dan dapat memberdayakan masyarakat.

\section{PENUTUP}

Islam memandang kesetaraan gender antara perempuan dan lakilaki sebagai bentuk dari kehendak Allah yang tidak membedakan kedua lawan jenis tersebut, baik dalam ibadah maupun hukum-Nya. Hak-hak kemanusiaan yang melekat pada kaum perempuan adalah harus diberikan. Perempuan di Sulawesi Tengah, meskipun di beberapa instansi pemerintah telah diberikan hak-hak dan kewenangannya, posisi strategis mereka di Lembaga Eksekutif (kantor gubernur) maupun Lembaga Legislatif (kantor DPR) provinsi Sulawesi Tengah, belum maksimal diberikan. Hal ini terlihat pada pemberian posisi kepada mereka yang kurang menguntungkan bagi kaum perempuan di daerah ini. Dalam hal peran, perempuan di Sulawesi Tengah masih terkesan dimarginalkan. Hal ini disebabkan oleh pemahaman agama dan adat-istiadat yang sangat peternal, kurang mempercayai kemampuan dan kualitas perempuan. 


\section{DAFTAR PUSTAKA}

Abdullah, Irwan. 1996. Reproduksi Ketimpangan Gender, Partisipasi Perempuan dalam Kegiatan Ekonomi dalam Dilema Perempuan; Antara Kegiatan Domestik dan Rumah Tangga. Yogyakarta: Aditya Media.

al-Bukhari. t.th. Shahih Al-Bukhari. Juz 2. Indonesia : Maktabah Dahlan.

al-Munawar, Said Aqil. 1999. "Kepemimpinan Perempuan dalam Islam, Membongkar Penafsiran Surah An-Nisa Ayat 1", dalam Syafiq Hasyim, Kepemimpinan Perempuan dalam Islam. Jakarta: JPPR.

Departemen Agama RI. 1989. Al-Qur'an dan Terjemahnya. Semarang: Toha Putra.

Fakih, Mansour. 1996. "Posisi Kaum Perempuan dalam Islam, Tinjauan dari Analisis Gender" dalam "Membincangkan Diskursus Gender Perspektif Islam". Cet. II. Surabaya: Risalah Gusti.

Hasyim, Shafiq (Ed.). 1999. Kepemimpinan Perempuan dalam Islam. Jakarta: JPPR.

Naisbitt, John dan Patricia Aburdene. 1990. Sepuluh Arah Baru untuk Tahun 1990-an Megatrend 2000. Alih bahasa oleh FX Budiyanto. Cet. I. Jakarta: Bina Rupa Aksara.

Partanto, Pius A. dan M. Dahlan Al-Barry. 1994. Kamus Ilmiah Populer. Cet. I. Surabaya: Arkola.

Raqib, Moh. 2003. Pendidikan Perempuan. Cet. I. Purwokerto: Gama Media Kerjasama STAIN Purwokerti Press.

Shihab, M. Quraish. 1993. "Konsep Perempuan menurut Qur'an, Hadis, dan Sumber-sumber Ajaran Islam", dalam Leis M. Marcoes-Natsir dan Johan Hendrik Mauleman, Perempuan Islam Indonesia dalam Kajian Tekstual dan Kontekstual. Jakarta: INIS.

Suhardiany, Dini. 2002. "Gerakan Perempuan Sebagai Kekuatan Oposisi", Buletin Postra, Islam Politik dan Demokrasi. Edisi III. Jakarta: ISIS. 